Grażyna Zarzycka

University of Lodz, Lodz, Poland

\title{
Managing discourse in conversation during lessons of Polish as a foreign language
}

\section{Introduction}

In this paper I report on a study of interactive discourse in Polish as a foreign language (PAFL). I begin by outlining the achievements of Polish glottodidactic philologists, who became interested in the issues of conversation in PAFL and discuss the necessity of their cooperation with discourse researchers of other languages. However, the main focus of this paper is on the processes taking place in communication in Polish as foreign language during the Polska a Unia Europejska (Poland and the European Union) conversational session. This event is an example of fulfilling the assumptions developed by the author and a group of dialogue pedagogy. Those assumptions, as well as the scientific and philosophical inspirations which form the basis of this pedagogy, will be presented in part three of this article.

In the theoretical-analytical part of the paper the notion of discourse management will be defined and the discourse management strategies related to particular phases of a conversational session will be discussed. In the following sections of this part a quantitative and qualitative analysis of conversation will be conducted. Conclusions about discourse dynamics will be based on quantitative research, consisting in establishing the percentage of participation in conversation by each of the interlocutors. Qualitative analysis of discourse management means will be limited to two key interlocutors. The analytical part will be supported by examples of interactions involving the aforementioned speakers. On the account of limiting the analysis to just one conversation, I see this research as a case study. 
Does a conversation taking place during a PAFL class have to be managed by the teacher? Can a person still studying a foreign language-one using interlanguage-manage a conversation in the target language as well? What conditions must arise to grant a student the role of a discourse co-manager? When does classroom discourse taking place in a foreign language class have the characteristics of natural discourse? In what situations is it merely didactic discourse? How to manage a conversation in a foreign language for it to become a tool for effective acquisition of new syntactic structures or lexical units, without it losing the characteristics of natural behavior? Research focused on defining the roles of key interlocutors manages to answer, also indirectly, the aforementioned questions, posed by many researchers of interactive discourse in a foreign language classroom. The answers to these questions will be offered in part five which serves as a summary of the present paper.

\section{Polish glottodidactic philologists' output regarding the interactive discourse research}

\subsection{Own research}

I have been conducting research on the interactive processes in PAFL, with short breaks, since the early 90s. It is when I took up research on the socio-linguistic behavior among foreigners studying the Polish language in The School of Polish for Foreigners at the University of Łódź (SJPdC UŁ) in a multinational student group (Podsiadły and Zarzycka-Suliga 1991). I kept a journal of socio-linguistic behaviors of the students in my group: after each class I would take notes of any spontaneous acts of communication that students undertook among each other or with the teacher, taking into consideration the changes in the students' interlanguage in connection with the development of social and cultural competence of foreigners. Thus, I was using typical ethnographic methodology.

The effect of this research (conducted in Poland, but largely supported by the literature I had the opportunity to familiarize myself with during a scholarship in the USA) was my doctoral dissertation on intercultural dialogue occurring between the members of a multinational students' group studying Polish language in SJPdC UŁ and at the same time being subject to the adaptation process (Zarzycka 2000a). The application of ethnographic methods allowed me to analyze many interesting communication occurrences and discuss the means of forming a communicative and intercultural competence (Zarzycka 2000b, 2001a, 2002, 2006) of those studying PAFL in various student groups. The use of Sinclair and Coulthard's (1975) classroom discourse research methodology allowed for better analysis of the form that their communication assumed. In my research, I also frequently made use of conversation analysis, basing my approach on methodological guidelines 
given by Deborah Tannen (e.g. 1994). Among the subjects of my works was the negotiation of meaning in oral communication in PAFL (Zarzycka 1998), types of interference in intercultural communication (Zarzycka 2001b), culturally conditioned conversational styles in oral communication in PAFL (Zarzycka 2003) and methodology of research on communication during foreign language lesson (Zarzycka 2001a, 2003, 2006). The subject of one of the papers was written interaction analysis of letters addressed by the SJPdC UŁ students from North Korea to their teacher; it allowed to show how the interlanguage of those students had been marked with propaganda.

Summarizing this part of my paper, I can only say that since the very first days of my work as a teacher of PAFL I was aware of the great power of dialogue (see Zarzycka $2006^{1}$ ) and the need to study what happens during a conversation, especially one taking place in the course of learning/acquiring a foreign language (more on this topic in the next part of this article).

\subsection{Works by other researchers}

Unfortunately, I regret to say (as an advocate of dialogue methods in foreign language teaching) that Polish language glottodidactics, which has been evolving so vigorously over the last twenty years, does not have many achievements in the field of research on the interactive process to its name. Reviewing the collections of works which are the result of international conferences organized under the sponsorship of the 'Bristol' association and the glottodidactic chairs/university centers teaching PAFL only confirms that this topic has rarely been investigated. Research on the natural language in the process of communication (see: the best examples of such research in: Majer 2003 and Pawlak 2004) remains scarce in Polish language glottodidactics (see Ostromęcka 1996). The result of this overview surprised me, especially since the last two decades in foreign languages teaching (including PAFL) have been a period of solidification of the communicative approach, in which speaking- interaction-language communication is a priority.

This does not mean that there has been no change in this regard. At the University of Wrocław, Anna Żurek's (2008) work is an interesting monograph in which she examined selected aspects of language etiquette of foreigners studying Polish with the use of a large-scale poll research. The research is pragmatic in character-the respondents were asked to finish dialogues simulating certain diversified social situations: requests, greetings, thanks/compliments/apologies, farewells and more. Their task was to impersonate people of various status. In fact, the author managed to obtain samples of behaviors of interactive character, namely, made up dialogues in written form.

This work contains further discussion of research described in this article, see footnote 10. 
A very interesting work by Karolina Kowalcze (2009) proves that examining interactive processes connected with learning, acquisition or multilingualism is starting to be an important field of research. The researcher proposed to look into the specifics of monologue and dialogue of bilingual siblings, using-among others-Bakhtin's speech genres theory, the studies on bilingualism by Anna Wierzbicka, and concepts recognized by discourse and conversation analysis. The study involves both oral and written language, as letters and fragments of polls are also analyzed.

The Polish glottodidactics community, actively connected with certificate exams in Polish as foreign language, came up with the idea of recording extracts of oral examinations, comprised of interactive tasks (B1 level), monologues, utterances based on stimulating material, or forming opinions about the read text, in addition to a conversation with the examiner. The recordings and transcripts could become the origin of student text corpus; see Majer's postulates (2003: 440) on the need of establishing student corpora and his assumptions described in the work by B. Lewandowska-Tomaszczyk (2005: 201-239). We are also considering creating such a corpus at the University of Łódź in which foreigners' Polish spoken during or in-between classes could be included.

Another opportunity is given by MA seminars, focused on the analysis of the language spoken by foreigners learning Polish. The origin of this type of research are the topics undertaken by two of my graduate students. One of them (Anna Gołosz) is examining students' of Polish as a foreign language communicative ability in the area of spoken code on the B1 level. The other student has taken up research on the ways the teachers communicate with the foreigners learning Polish as foreign language and this research has already led her to interesting conclusions about feedback as the basic text in the teachers' discourse with foreigners (Sokołowska 2011).

\subsection{Postulates}

The analysis of interactive process, exciting as it is, is at the same time hard-it demands a large amount of work: firstly to acquire the recording of a conversation, then to create a transcript and finally the analysis itself. Examining spoken discourse-including foreign language-demands researchers to familiarize themselves with rich literature on foreign language learning. Polish researchers relying only on works in Polish by other Polish researchers will never have a chance (unless they reach for the voluminous foreign literature, especially in English) to fortify their knowledge about examining interactive discourse. This is why they should be stepping out of their closed scientific community and using the opportunity to exchange thoughts with neophilologists as often as possible, in order to not discover what has already been discovered by researchers in other 
countries-here, I agree with Anna Niżegorodcew (2009: 11-19). In my opinion there is also an extensive need for popularizing some of the foreign language works in the Polish language, to begin with works by professor Jan Majer (2003) and Mirosław Pawlak (2004).

\section{Dialogue pedagogy assumptions}

Such pedagogy supports the development of students' competence in PAFL as spoken language and had been formed during my work with a group of intermediate-level foreign students learning PAFL at SJPdC UŁ in the academic year 2004-2005. It is based on conversations that took place during the so-called conversation sessions. This method is to some extent the effect of a glottodidactic conversion of the dialogue idea presented by the British physicist and philosopher David Bohm (1996), and also to some extent the effect of an idea conceived spontaneously in the student group.

\subsection{Summary of David Bohm's ${ }^{2}$ philosophy of dialogue}

David Bohm is the advocate of the group dialogue technique. In his opinion dialogue groups should meet systematically and carry out conversations without a moderator or specific goals. During group conversations interlocutors establish common meanings - this takes place when they become influenced by the dialogue's rhythm and open up to different points of view-what follows is a new, profound understanding of themselves and others as well as changes in the interlocutors' identity. A dialogue group should consist of 20-40 people ${ }^{3}$, only then can it be an image of 'social microcosm' in terms of interlocutors' diversity (mental and awareness differences etc.). When such group establishes a common point of view on a particular issue, the process of social bonding starts-the dialogue group transforms into a closely knit 'cultural group' (Bohm: 1996: 9-15) ${ }^{4}$.

According to Bohm (1996:6),

[a] dialogue can be among any number of people, not just two. Even one person can have a sense of dialogue within himself, if the spirit of the dialogue is present. The picture or image that this derivation ${ }^{5}$ suggest is of a stream of meaning

2 In Bohm's dialogue philosophy there are trails of Bachtin's dialogue theory as well as Krishnamurty's philosophy, who was a friend of Bohm's.

3 Everyone should be sitting in a circle, which according to Bohm is impossible in a larger group of people.

4 Does this view not correspond with the concept of 'the third culture', which emerges during foreign language teachingwith the use of dialogue methods (see Kramsch 1993)?

5 Bohm derived the meaning of the word 'dialogue' from Greek dialogos, where logos means 'word/meaning of the word' and dia means 'through', not 'two' (ibid) 
flowing among and through us and between us. This will make possible a flow of meaning in the whole group, out of which emerges some new understanding. It's something new, which may not have been in the starting point at all. It's something creative. And this shared meaning is the 'glue' or 'cement' that holds people and societies together.

\subsection{Dialogue pedagogy in the glottodidactic practice}

- Because of the fact that conversation without a purpose is in glottodidactics often treated as a didactically useless tool (see Lipińska and Seretny 2005:176 ) - though, as a glottodidactics practitioner and a dialogue theoretician the same time, I find it hard to agree with ${ }^{7}$ - the student group together with the teacher decided to talk about topics interesting for the whole group.

- An interesting topic was meant to incentivize students to speak. This assumption stays in agreement with various methodologies of teaching speaking skills in foreign languages (see Lipińska and Seretny 2005:176-177, Komorowska 2005: 196-205, Byram 2005: 563-566).

- To prevent the teacher from dominating the conversation, for every session a moderator was chosen (except for the first and the last one-here, the teacher was also the moderator).

- The topics of conversations were chosen during joint negotiations. These were as following: Session 1: Foreigners and their lives in Poland (the teacher served as moderator, with substantial spontaneous participation by a Tunisian student); Session 2: Abortion (a French student was the moderator); Session 3: Poland and the European Union (a German student as moderator); Session 4: Marriage or open relationship (moderated by an Egyptian student), Session 5: Conversation about conversation (the concluding conversation, led by the teacher, making use of a prepared questionnaire). During conversations, the group resigned from the session entitled: Is it worth listening to the Pope? as it was decided that the problem had been covered during Session 2.

$6 \quad$ This is the comment from a famous methodology guide for Polish foreign language teachers in the chapter on practicing speaking skills: “One shouldn't learn »speaking as such «; one shouldn't also practice communicational situations which are unnecessary for a particular group. (The statement was put in a frame to emphasize its value: G.Z) The basis of teaching speaking skills are vocabulary and syntax structures, provided and acquired in advance."

7 See the discussion presented in Jan Majer's monograph on the didactic role of interaction during the lesson of a foreign language, particularly its conclusions (Majer 2003: 431-440). I am entirely convinced about the accuracy of the statement: interactive discourse should be used as a tool for creating learning opportunities in the language classroom (ibid: 431). That is why a spontaneous conversation during a foreign language lesson, even if not included in the lesson schedule, is in my opinion always of positive value- a tool that serves gaining language competence. 
- The manners of carrying out conversations were not imposed on moderators and they did not have to make any written schedules, though in practice it appeared that each of them had their participation in the discourse prepared (by reading appropriate books, browsing the Internet, conducting interviews and conversations, asking their families and Polish friends for their opinion and also for help in their preparation-like in the case of the Egyptian student, married to a Polish woman).

- A few days before a session the teacher gave the moderator press articles which could be the source of knowledge and inspiration for him or her.

- Before one of the more difficult sessions (Abortion) the teacher decided to talk over the vocabulary related to what was to be the topic of the discussion the following day. The basis for the preparation was an article from an encyclopedia.

- The sessions took place in 10-14 days' intervals as a part of five-hour lesson blocks (specifically, at the beginning of the block). Even though the length of a single conversation lesson had not been specified, in practice they lasted from 45 to 60 minutes; after this time the conversations naturally ran out.

- The ensuing social-discursive happenings were to be the holiday of conversation. The holiday during which the conversation was 'celebrated' in a similar way to how poetry is celebrated in Claire Kramsch's (1993) 'readers theatre' method, one of the techniques she elaborated for the use in foreign language dialogue teaching (compare also: Zarzycka 2010).

- Celebration of conversation assumes its essential role in the development of personal, social and language skills-significant influence of conversation on the growth of consciousness, empathy, language skills. Furthermore, when the conversation is carried out by a multinational student group, it favors-more than any other tool—-the formation of intercultural ${ }^{8}$ sensitivity and competence.

- Participants of the conversation sessions claimed that their participation in the sessions let them form bonds, helped them develop their receptive and productive language skills, and also had cognitive and even therapeutic functions. ${ }^{9}$

All conversational sessions were recorded on an audio tape, which allowed for the analysis of different communication aspects; for the teacher himself it gave an opportunity for self-evaluation.

$8 \quad$ As intercultural sensitivity I mean readiness to be open-minded towards the issues of the Others, in other words- a positive approach towards the others and otherness in generis, whereas the intercultural communicational competence I see as an ability to manage the process of exchanging meanings in a situation, when there are barriers resulting from cultural differences between the receiver and the sender of the message. I develop this issue further in: Zarzycka 2008.

9 I demonstrated the effects of the first conversation session in detail (Foreigners and their lives in Poland) and of the last one (Conversation about conversation), with participants' evaluation included in the article Moc dialogu (Zarzycka 2006). 


\section{Methods of discourse management during the conversation session Poland and European Union-a case study}

\subsection{Discourse management-term definition}

For the purpose of shaping the definition of the term discourse management I would like to call on the dictionary definitions of the word management, understood as controlling something or somebody. Furthermore, the activity of controlling something is compared in dictionary entries to steering a ship/vehicle. The metaphor of discourse management as steering, being a helmsman, being at the helm seems accurate to me-conversation (similar to a ship voyage) is an act of spontaneity, thus unpredictable to some extent. Although when we are looking at a ship, sailing on the sea we have an impression that it moves itself. This happens only when it loses its steerability, when the helm gets damaged or when there is nobody at the helm. It is a similar case with a conversation- somebody (in different stages it could be a different person) has to give the direction of a discussion so that it is meaningful and logical.

Compare the definitions and contexts presented in Inny słownik jezyka polskiego (Bańko 2000 volume P...Ż), illustrating those associations:

- 'To manage' - If a person or institution manages a company, household, assets etc it means that they control it' (ibid. 1268).

- 'Helmsman' - 'Helmsman is a person who steers a ship or a boat'.

- 'To steer':

1. 'If someone steers a vehicle, most often a car or a plane, they give direction of its movement with a tool, for ex. a helm or an oar. I can steer a boat... The captain ordered to steer towards the land... Children were sledging along the middle of a sloping street, most often lying on their stomachs, steering with their legs.'

2. 'If a person or a mechanism is steering a device, they have influence on it and determine its direction. It is a multipurpose machine that works in an automatic cycle(?) which may be steered or programmed manually... An instrument that steers the switches' activity... Remotely steered toy car.'

3. We say that 'someone steers some actions, processes or people if they influence and control them. Since 1932 Józef Beck had been steering Polish foreign policy... switching from centrally planned economy to market economy... It happened that colonist authority appointed tribal leaders, selecting people skillfully so that it would be easy to steer them' (ibid. 688).

- Steering. 'Steering is something that is used to control... steering wheel... steering lever (ibid.).

- Driver. 'Driver is an electronic mechanism, which is used by the operating system to control the work of a peripheral device, for example printer or an 
automatically controlled machine tool' (ibid). (I'd consider dropping that entry entirely).

- Steerable. 'Steerable vehicle is that which can be steered or controlled easily. The more stable is the bicycle, the less steerable it is'(ibid.).

- Steerability. 'The plane lost its steerability' (ibid).

I assume the following definition of discourse management:

I understand discourse management ${ }^{10}$ as controlling, which could be compared to steering a ship, voyaging through the sea. Discourse management is steering it, being a helmsman/being at the helm, understood as assigning the direction of the discourse (ex. conversation or a discussion), influencing its course. Discourse management is neither about taking an absolute control over it nor about steering understood as programming the actions of people engaged in its creation ${ }^{11}$. (Would such a programmed conversation actually still be a conversation?!)

\subsection{Discourse management strategies}

Continuing these considerations and relating the above definitions taken from Inny Słownik Języka Polskiego, it is possible to define competences of a person who conducts classroom discourse managing:

A person managing a classroom discourse-steering it on a macro level- should be able to activate and make use of the steering mechanism: a helm, a steering. During the foreign language lesson there is usually a teacher at the helm, and the steering mechanism are his/her language skills, status in the group-his/her attributed managerial position.

Classroom discourse analysis enables us to come up with the following theses on discourse management strategies:

- Usually, a language teacher controls the discourse during the lesson in a traditional way: asking someone for an answer, encouraging someone to voice their opinion in the conversation etc.

- Teacher can hand the helm over (usually only for a limited period of time) to another interlocutor. This happens only when the teacher asks someone who learns language to direct conversation on one's own (only at this point are we dealing with real helm surrender).

- When conversation proceeds without the signs of breaking down, the teacher standing at the back expresses his/her support for the actions undertaken by the learners spontaneously he/she uses signals of support (verbal and non-verbal), reacts to the students' utterances in an affirmative way.

$10 \quad$ I take discourse as every communication exchange.

11 Therefore, in my discourse management definition I appropriate the, dictionary definition of 'steering' as meaning 1 . and 2. while rejecting the definition of steering as meaning 3. (as in total control over somebody or something) 
- Foreign language teacher, however, is always close to the helm and if he/ she has an impression that the ship (discourse) loses its direction, he/she undertakes remedial actions (putting something under negotiations or correction, commenting on a discourse fragment, paraphrasing its meaning, asking another interlocutor to join the conversation, repeating a discourse fragment etc.) to steer it back on course.

- Sometimes the students as conversation participants try to take over the helm on their own (they join the conversation independently, ask inquiring questions, form interesting statements-moving the discourse forward and causing it to develop). One could say that these are the key speakers, essential to the discourse run-they co- manage it (control fragments of the discourse).

Numerous works by foreign researchers (compare Majer 2003), in addition to the results of my own research, enable us to come up with another thesis, determining the uniqueness of classroom discourse carried out in the target language:

During a foreign language lesson the teacher almost always manages the entirety of the discourse, even if the moderator of the discussion/ conversation was previously appointed. But to call the discourse spontaneous, THERE HAS TO BE ROOM LEFT for co-operation in the discussion, exchanging points of view, or switching roles. ${ }^{12}$

\subsection{The phases of discourse management process}

During a conversation on a particular topic, as in the instance of the Poland and European Union conversation session, discourse management was divided into distinct segments. In each phase one could distinguish specific ways of discourse management:

- during preparations for a conversation session-session planning: specifying the topic, appointing the moderator, setting the conversation time etc.; in our case study management in this phase had a collective character;

- during its course-managing the conversation while it took place; during the analyzed conversation session usually the teacher was at the helm, but in many cases that responsibility was handed over to the moderator; joining the conversation on one's own was the Tunisian girl, and also (rarely) the Egyptian;

- during the post-conversation discussion-in this phase the conversation often takes the form of metadiscourse-feedback and evaluation of a particular communication event. The most important effect of discourse management in this phase is (from the teacher's point of view) enriching the competence in discourse management in the future; compare conclusions from the conversation session number five: Let's talk about talking in Zarzycka (2006).

12 Discussion on the conditions for a spontaneous conversation during foreign language lessons was presented in an interesting way in: Majer (2003: 14-16 and further) 


\subsection{Controlling discourse throughout its duration}

In this part of the article, by using quantitative and qualitative analyses we will examine a few important aspects of the interactive discourse management during a lesson of Polish as a foreign language. The analyses will be illustrated with fragments of transcripts from the Poland and the European Union session.

$* * *$

Date and place of the conversation: 13 December $2004^{13}$, SJPdCUŁ

Length of the recording: 55 minutes.

Participants of the conversation session:

intermediate level group B1+ (3rd month of language learning)

the teacher (W) (Polish), Sameh (M) (Egypt), Anna (Georgia), Guneł (W) from Azerbaijan, Khasan (M) from Uzbekistan, Peter from USA, Sonia from Tunisia, (Polish descent), Thomas (Germany, Polish descent.) ; M-man, W-woman.

\section{Marks used in the transcription:}

- (?)-hesitation in speech.

- ...-continuing the utterance.

- CAPITAL LETTERS—-words emphasized by the interlocutors.

- If an utterance is only a confirmation signal it is put in a square bracket within the given interlocutor's utterance.

- Underlining was used for the so called movements ${ }^{14}$-important elements of discourse, where the topic or plot of the conversation changes: creating an impression of conversation development.

- Dark grey color was used to mark the words important for the topic development, phrases given in an inappropriate or approximate form, negotiation during conversation.

- Pale gray was used to mark the words important for conversation development, phrases given in an inappropriate or approximate form, but not negotiated during conversation; the teacher and other conversation participants made a decision not to correct them.

$13 \quad$ The session was carried out after Poland became a member of the European Union.

14 According to the terminology by Sinclair and Coilthard (1975) the smallest unit in discourse is an utterance-everything that one interlocutor said before another one-it is where Sacks and Schegloo (Sacks 1992) introduce the concept of turn; another level of discourse is an exchange, which consists of at least two utterances. Moves are those elements of utterance, which make the conversation develop, since they contain the so called boundary elements, e.g. questions. 


\subsubsection{Who stands at the helm?}

\subsubsection{Quantitative data}

The quantitative analysis showed great dynamics of this conversational session, in which 320 turns were noticed. Linguistic corrections were also included here. Signals of agreement (Aha, yhm, exactly) which did not interrupt the utterance of one of the interlocutors were not counted as turns. Thirty-seven of those signals were noted, half of them with the teacher's participation.

The percentage of participation of particular interlocutors, counted by the number of their turns (utterances), or 'entries' into the conversation, was as follows: Teacher-148 turns (circa $\left.47 \%{ }^{15}\right)$; including 38 turns $(25,7 \%$ of her utterances) consisting only of linguistic corrections; Thomas (moderator of the conversation)-98 turns (ca. 30,6\%). Other participants: Sonia-the participant who joined independently the most often-40 turns (12,5\%), including linguistic corrections; Sameh: 11 turns (ca. 3,6\%) + participation in the 'choruses'-coutterances of several people; Peter: 7 turns (ca. 2,2\%) + participation in the 'choruses'; Gunet: 6 turns (1,9\%); Khasan: 1 turn $(0,3 \%)$, being a refusal to take part in the conversation. Everyone (choral utterances) -4 (ca. 1,25\%). Anna's active participation was not recorded.

The length of particular turns: from one word or utterance (linguistic corrections would often take this form) to a multipart utterance ${ }^{16}$. The longest utterances were produced by the key interlocutors.

\subsubsection{Conclusions}

After deducting language corrections carried out by the teacher, which considerably solidified her image of the dominant side in the dialogue, we can acknowledge Thomas as the co-manager of this conversation-together with the teacher and Sonia. The principal role of the teacher may appear to be macrodiscourse control. Thus, she becomes the supermoderator.

Below, I will talk over the means of managing discourse during this conversational session, focusing my attention on the roles and communicative actions of the two key interlocutors-the teacher and Thomas.

$15 \quad$ Interestingly, the same percentage of turns by the teacher and Thomas was achieved during quantitative analysis of the first, much less dynamic (consisting of 170 turns while the duration was similar) conversational session, which was moderated only by the teacher; compare Zarzycka 2006.

16 Particular elements/ segments of utterance in discourse are separated by pauses or interruptions: yyy, eee, $\mathrm{hmm}$ etc. 


\subsubsection{Controlling the macrodiscourse- the teacher's role}

The teacher assumes the responsibility in this field, ensuring the fluency of conversation; below is the initial fragment of the discourse (its initiation):

(1)

L: All right then. can we start the conversation? Poland and the European Union. Unfortunately ---, among the countries of the old European Union, we only have a representative of Germany. Is that right? And I am a representative of a country, the new country of the EU. Mister Sameh from Egypt, Miss Ania from Georgia, Miss Guneł, from Azerbaijan, Mister Khasan from Uzbekistan, Piotr from the USA, Sonia from Tunisia and Tomasz from Germany. Tomasz is leading the discussion today.

The teacher also dominates the final phase of the conversational session. She ensures it concludes properly, and at the same time she takes up the actions meant to protect Thomas' status, because it is the moderator who should sum up the conversation:

L: [...] Będzie musiała robić .... jako CZŁONEK Unii Europejskiej. Panie Tomaszu, jeszcze trzy minutki, może jakieś zakończenie, proszę bardzo?

Th: Chce zapytać, czy wy macie jakieś yyy yyy ------ [10 sek. pauza]. Aha, czy wy macie w ogóle, myślicie może, jakieś zalety, (1) abo [aber?], a nie, korzyści, korzyści, że wy (2)macie jakieś korzyści oso osobiste przez to(3), że yyy Polska weszła do Unii?

L: Jako cudzoziemcy, którzy są w Polsce, tak?

(1) Grammatical error.

(2) Redundant use of a personal pronoun.

(3) Lexical error.

L: [...] It will have to do... as a MEMBER of the European Union. Tomasz, three more minutes please, maybe some ending, please?

Th: I wanted to ask do you have any yyy yyy----- [10 sec. pause]. Ah, do you have any at all, any advantages, ar [aber?], oh no, advantages, advantages, that you have any pers personal advantages from yyy Poland entering the Union?

$\mathrm{S}$ : As foreigners living in Poland, right?

(3)

L: Prestiż Polski wzrósł i wzrósł prestiż polskiego dyplomu, prawda? [So: Tak.] Jakie zakończenie, Tomasz, jedno dwa zdania?

Th: Aha, no to, nie, ale widzę, że że grupa z moją opinią i może takie, że zgadzam się najwięcej z tymi. (4)

L: Dziękuję serdecznie i brawo Tomaszowi za przygotowanie a Państwu za udział!

(4) Sentence consisting of unfinished clauses. 
L: Poland's prestige grew and Polish diploma's prestige grew, right? [So: Yes.] What would the ending be, Tomasz, in one-two sentences?

Th. Ah, so no, but I can see, that that the group with my opinion and maybe such, that I agree the largest with those.

Being the supermoderator is expressed through paying attention to the authenticity of the discourse as well; compare the teacher's reaction to Thomas' excuse, which in fact is a metadiscursive comment-a reprimand, presented in fragment (4):

Thomas (Th): I'm sorry, I have a problem, that I've forgotten this text that I wrote.

But yes, I think that I remember well.

L: But text is to be read, and this is supposed to be a conversation, discussion.

Maybe it's better that You don't have it. Please!

The underlined fragments of the teacher's utterance (movements) play the causative role-they are meant to motivate Thomas to take the role of the one leading the conversation-the role which he accepted earlier. Thomas, however, is not moderating this conversation in its entirety, as it is still the teacher who oversees the correctness and relevance of his moderator statements-she takes care of their precision, looking for his confirmation that she understood his intentions correctly. The teacher at the same time controls the process of acquiring new content by the dialogue group-hence her notes from the discussion on the blackboard-ta ken on the spot during particular interlocutors' turns.

Though Thomas asks the key questions, allowing the conversation in this phase to develop, it is the teacher who assigns the roles to specific interlocutors, making them think and speak (using characteristic expressions for her individual conversational style: So I (kindly) ask (you to speak) / So please think about the answers / After all everyone can have their say.../ So how would you solve this situation? etc.).

Below there is a longer fragment, illustrating this multidirectional discourse control by the teacher:

(5)

Th: No, może ja dla grupy, żeby startować taką dyskusje, (1) może yym yym zaczynam: jak myślicie, na przykład yym jak w ogóle yym Polacy stoja (2), można powiedzieć, do roboty, (3) jak, jak oni

$L$ : Jaki jest stosunek Polaków do pracy, tak?

Th: ...czy myślicie, że Polacy sa, że większość Polaków jest bardzo pilny (4), i czy w ogóle mają ten interes wykorzystać (5) tych (6) nowych możliwości, które się teraz (7) [dały?; fragment mało czytelny] przez to...

L: Czyli Pan stawia tutaj dwa pytania, prawda. Czyli pierwsze pytanie Pan stawia grupie takie: co myślicie o Polakach, tak?Th: Nie.

$L$ : No to, proszę, jeszcze raz.

Th: Nie, czy Polacy są yym, jak (8) oni mają relacje (9) do roboty (10). Czy oni są [Włączają się studenci, poprawiając frazę.] 
$L$ : Jaki mają stosunek do pracy.

Th: Jaki mają stosunek do pracy.

$L$ : Ja zapiszę to pytanie, dobrze?

Th: ...bardzo pilny, czy bardzo, według was: bardzo pilny(11) czy bardzo leniwy (11), czy większość Polaków—jak (12) oni są? I czy myślicie, że mają też w ogóle interes wykorzystać (13) te możliwości, które mają przez przez to (14), że Polska jest teraz w Unii Europejskiej?

L: Czy są pracowici, czy są obowiązkowi. No to nie wiem, czy każdy z Was może się wypowiedzieć, musicie się zastanowić, czy wiecie dużo na ten temat. A jak to drugie pytanie zapisać: czy Polacy chcą wykorzystać szanse, które daje im Unia Europejska? Związane z pracą, tak?

Th: Tak.

$L$ : No to proszę myśleć nad odpowiedziami.

[Pauza 6-sekundowa; w tym czasie lektorka zapisuje pytania na tablicy.]

$L$ : [kontynuując pisanie, zwraca się do Thomasa] związane z pracą za granicą, o to Panu chodzi?

Th: Tak.

$L$ : No to bardzo proszę się wypowiedzieć. Kto z Państwa chciałby na któryś z tych tematów się wypowiedzieć?

(1) Lexical error-word used in wrong context.

(2) As above, probably result of linguistic calque.

(3) Stylistic error-use of a colloquialism.

(4) Grammatical error-wrong adjective declension.

(5) Grammatical error-words not in syntactic relationship (?).

(6) Grammatical error-wrong pronoun declension.

(7) Unfinished clause.

(8) Grammatical error-wrong pronoun declension.

(9) Lexical error.

(10) See (3).

(11) Words "pilny" I "leniwy" cannot be used to describe "stosunek" (?).

(12) Grammatical error-see (8).

(13) See (5).

(14) Lexical error-word used in wrong context ("przez to" implies a negative outcome).

Th: So, maybe me for the group, To begin such discussion, maybe yym yym I begin: what do you think, for example yym so anyway how do Poles stay let's say towards job, how, how do they

L: You wanted to say what is Poles' attitude towards work, right?

Th: ...do you think that Poles are, that most Poles is very diligent, and do they at all have this interest to use those new opportunities, which now made themselves [available?; unreadable fragment] because of this...

L: So You are asking two questions here, right. So You ask the group about the first question: what do you think about Poles, right?

Th: No.

$\mathrm{L}$ : So one more time, please. 
Th: No, are Poles yym, what relation do they have to work. Are they [Other students join in, correcting the phrase.]

$\mathrm{L}$ : What is their attitude towards work.

Th: What is their attitude towards work.

L: I will write this question down, okay?

Th: ...very diligent, or, in your opinion, very diligent or very lazy, are most Poleshow are they? And do you think, do they have interest at all to use those possibilities, which they were handed because Poland is in the European Union now?

L: Are they hard-working, are they conscientious. So I don't know if every one of you can express their opinion, you have to think about it, if you know much about this. And how to write down this second question: do Poles use the opportunities that the European Union gives them? Connected to work, right?

Th: Yes.

L: So please think about the answers.

[six-second-long pause, in the meantime the teacher writes the questions on the blackboard]

L: [Still writing, speaking to Thomas] connected to working abroad, is that what you had in mind?

Th: Yes.

L: So please speak. Which one of you would like to speak on any of those topics?

Even when Thomas asks his interlocutors a question himself, the teacher repeats his utterances, models them, focusing on the precise transfer of content. And as the result, she is normally the person who picks out the next interlocutor.

Interestingly, regular corrections, as well as digressions-comments of metalingual character-do not interfere with the process of the topic's progression in this discourse; Thomas copes really well with this task despite all the language limitations. One explanation of this may be that the interlocutors are already used to a specific role of the teacher. Another one may be that linguistic corrections are connected to the negotiation of meaning. If the speaker was not making the corrections on the spot, would it be possible to speak about collective emerging of common meanings in this dialogue?

Below are a couple of excerpts from this dialogue, where the control of language correctness is strongly connected to modeling the content of the statement. In a dialogue on a 'specific topic' it seems to be essential:

(6)

Th: ...tych wartości. I może właśnie powiem najpierw, kto jest obywatel w tej Unii Europejskiej. Do dwutysiącnego czwartego roku piętnaście, Unia Europejska miała piętnaście yym, eem, państwowych obyw, państwowych obywatel (1ab), czy (?)

L: Do Unii Europejskiej należało 15 państw, tak?

(1a) Lexical error - no such collocation + "obywatel" can't refer to a country.

(1b) Grammatical error "obywatel" is in singular instead of plural form. 
TH: ... of those values. And maybe I will first say, who is citizen of this European Union. Until 2004 fifteen, the European Union had fifteen yym, eem, national citi, national citizen, or (?)

L: 15 countries belonged to the European Union, right?

Th: To przez to na przykład, że jest ORWO i te, te, wszystkie kraje w Unii mają, są łączone razem, praktycznie wojna w Europie już nie jest, już nie można sobie wyobrażać, prawie niemożliwa. Eee, poza tym, cel Unii Europejskiej jest eee, eee, nie wiem, jak to mam powiedzieć, yym, dokonać (1), może, dobryt (2ab) we wszystkich państw, wszystkich państw, yyy, yyy

L: Może: zapewnić DOBROBYT [akcentuje słowo]. [Th: No.]

Sonia [So; staje w obronie kompetencji językowej Thomasa]: - On dobrze napisał...

L: No to dlaczego tak przeczytał? Może jakby Pan nie czytał, byłoby lepiej.

Th: Nie, nie, ja nie czytam, ja tylko parę [słowo niezrozumiałe] notes, notatki (3), szybko, szybko...

$L$ : No to jaki zapiszemy drugi punkt?

Th: No, że wszystkich kłol, yyy, eee, że członkowych (4) państwów (5)

$L$ : Państwa członkowskie, uwaga! [...]

(1) Lexical error.

(2a) Formative error.

(2b) Grammatical error-word not inflected.

(3) Inserting an English word and wrong noun declension.

(4) Lexical error.

(5) Formative error.

Th: It is because for example, that there is ORWO and those, those, all countries in the Union have, are connected together, war in Europe is practically no longer, You can't imagine, almost impossible. Eee, besides, the aim of the European Union is eee, eee, I don't know how to say it, yym make, maybe, welling (should be indicated that some sounds were missing) in all countries, all countries, yyy, yyy

L: It can assure the WELL-BEING [emphasizes the word]. [Th: No.]

Sonia [So; defends Thomas' linguistic competence]: He wrote correctly...

L: So why did he read it like that? Maybe if you didn't read it would be better.

Th: No, no, I don't read, I just a few [unintelligible word] notepad (?), notes, quickly, quickly...

L: So how shall we write down the second point?

Th: Well, that all mem, yyy, eee, that all membered states

L: Member states, attention! [...]

Th: No tak. Yym. No inny aspekt jest ten, że w Unii Europejskiej jest bardzo ważny (1) to, że członki (2) spoczywe (3) państw są...

$L$ : PAŃSTWA CZŁONKOWSKIE, tak to się nazywa, tak? [pisze na tablicy]

Th: ...że są, żeby były tolerancyjne, nieotwarte(4), bo jednak są (5) dużo różnych, różne kultury, które muszą poradzić ( $5 \mathrm{ab}$ ) ze sobą i dlatego moje następne pytanie: czy myślicie, że Polska jest takim otwartym i tolerancyjnym krajem? 
L: Czyli można powiedzieć, że otwartość, tolerancja to są główne wartości, tak?, [Th: właśnie] propagowane przez Unię Europejską?

Th: To są ideały Unii Europejskiej

L: No dobrze, niech tak będzie: ideały Unii Europejskiej [zapisuje kolejne pytanie na tablicy]

Th: i, czy oni znajdują się też w Polsce, czy większość Polaków myśli, czy są otwarci do (6) innych yyy yyy

L: Otwarci na innych, tak? Otwarci w stosunku do innych, tak?

Th: Do innych yym -------- [pauza 10 sek.; tym czasie lektorka pisze na tablicy] i bardzo ważne też do [z wahaniem w głosie] do (7) mniejszości? Tak?

L: Otwarci na innych, tak?, otwarci na innych, tolerancyjni wobec mniejszości [powtarza w trakcie zapisywania na tablicy]

Th: Mniejszości, no tak. Jak wy o tym myślicie?

(1) Grammatical error-adjective used instead of an adverb.

(2) Lexical error.

(3) Formative error (?).

(4) Lexical error.

(5) Grammatical error-wrong conjugation.

(6a) Lexical error- "poradzić" implies conflict, solving a problem, where (in this case) one culture is a problem to another which must be solved.

(6b) Grammatical error-omission of the reflexive pronoun.

(7) Grammatical error-wrong preposition.

(8) See above.

Th: So yes. Yym. So another aspect is this, that in the European Union is very important, that members restive states are...

L: MEMBER STATES, that's the name, right? [writes on the blackboard]

Th: ...that they are, they should be tolerant, unopened, because however are many different, different cultures, which must cope each other and that is why my next question is: do you think that Poland is such open-minded and tolerant country?

L: So you could say that open-mindedness, tolerance are the main values, right?, [Th: exactly] advocated by the European Union?

Th: Those are the European Union's ideals.

L: All right, let it be this way: the European Union's ideals [writes down the next question on the blackboard]

Th: and, are they in Poland as well, do most of the Poles think, are they open at others yyy yyy

L: Open towards others, yes? Open in relation to others, right?

Th: Towards others yym -------- 10 sec. pause; in the meantime the teacher writes on the blackboard] and it is very important at [with hesitation] at minorities? Right?

L: Open towards others, right?, open towards others, tolerant of minorities [repeats while writing on the blackboard]

Th: Minorities, oh yes. How do you think about this?

Moderating the dialogue on the European Union proved to be a challenge for Thomas, due to his lexical limitations and deficiency in the field of operating 
advanced syntax schemes ${ }^{17}$. Because of that, the actions undertaken by the teacher were focused on negotiating the meaning and extracting (as well as preserving in the form of a note on the blackboard) the correct forms of terms, expressions and phrases (member states, assuring the well-being, maintaining peace, defense of values, structural funds, secularization, delocalization, attitude towards minorities, play a role, pay attention to adhering to standards, western companies, join the European Union, see benefits of Poland joining the Union) appearing in his utterances, which play a major role in this dialogue. Thus the teacher may be considered the architect of this discourse.

\subsubsection{An exponent and animator of the discourse- Thomas' role}

While the teacher manages the dialogue in many ways, maintaining its proper shape, having an influence on the participation of particular interlocutors in the dialogue, modeling of the meaning, and on linguistic correctness of particular utterances, Thomas' role is different.

First of all, he is the speaker who develops the conversation in terms of ideology. Despite him lacking in vocabulary, he seems (as a citizen of a country present in the European Union for very long) to be an expert on Union issues. He is capable of expressing the aims of the European Union (raising the standards of living, maintaining peace, providing well-being etc.) and directing ideologically interesting questions to other participants of the dialogue. His utterances contain the most moves-questions, addressing the interlocutors directly; see the underlined fragments in Thomas' previous utterances as well as in the fragment below:

(9)

Th: Mam pytanie jeszcze. Co wy myślicie o tym problem (1)... albo zapytam inaczej jeszcze, o tym, o tych (2), że stare kraje Unii Europejskiej się boją troche,, że Polska weszła, że te wszystkie te robotniki (3) przy, pójdą teraz do Niemczech, do Francji, do Anglii i yyy pracuja (4) za małe pieniadze i eee pieniędzy i yyy wezmą (5)...

$L$ : Zabiorą miejsca pracy.

Th: ...zabiorą pracy właśnie im. To co o tym myślicie? Czy...

$L:$ A może Pan Khasan by nam chociaż słówko powiedział?

Khasan: Nie mam nic do powiedzenia.

$L$ [śmiejąc się]: Nie chce Pan nam nic powiedzieć? Hyy! No to [lektorka zwraca się ponownie do Thomasa] stawia Pan pytanie, czy mają powody, tak [Th: Mają

$17 \quad$ Compare Thomas' problems with saying member states of the European Union illustrated in the examples (6), (7), and (8), and the compensation strategies he uses (linguistic innovations-lexical and syntactical *national citizen, ${ }^{*}$ steteses member, ${ }^{*}$ member stateses) 
powody, tak], mieszkańcy zachodnich krajów Europy, żeby się bać. Mają powody, czy nie maja, proszę!

(1) Grammatical error-wrong noun declension.

(2) Grammatical error-wrong pronoun declension.

(3) Formative error (?).

(4) Grammatical error-wrong conjugation (present instead of future tense).

(5) Unfinished clause.

Th: I have a question still. What do you think about this problem... or I will ask differently, about this, about those that the old countries of the European Union are afraid a bit, that Poland entered, that all those workies will co, will go now to Germany, to France, to England and yyy they work for little money and eee money and yyyy they take...

L: They will take away the jobs.

Th: ...they will take the job from them. So what do you think about it? Are...

S: Maybe Khasan would say at least a word?

Khasan: I have nothing to say.

L [laughing]: You don't want to tell us anything? Huh! So [the speaker turns to Thomas again] you are asking us if they have reasons, yes [Th: They have reasons, yes], the citizens of Western countries, to be afraid. Do they have any reasons or not, please!

Thomas is then in the same way the ideologist of this discourse, as he is its animator. In this second category he, of course, competes with the speaker, who being more fluent in using Polish, often knocks Thomas off stride, introducing digression to the dialogue or asking out other interlocutors for answers (because as the manager of the discourse at all of its levels, she fulfills goals overriding those of Thomas).

The transcript allowed to record the instances where Thomas copes with communicative tasks which require interpretation of statistical data, making an argument, and those where he skillfully imposes his own strategies of leading a discourse. Compare the fragment of the final discussion, where Thomas takes the floor away from the teacher, demanding to acknowledge his previously appointed role of the conversation's moderator:

Th: ...to ja jeszcze może bym chciał dokończyć. Ja mam podobne zdanie i myślę po prostu, że yyy, jakby ktoś robił tutaj, parę lat temu skończył studia, to by może w Polsce coś z tym zrobił, ale w innych krajach w Europie trudno mu było tam. No dobrze, w Polsce skończył studia, okej, nic takiego. A teraz właśnie, jak mówili (1) już tutaj osoby, że yyym...

L: Kiedyś trzeba było nostryfikować te dyplomy, jeszcze się jakieś dodatkowe egzaminy przechodziło, prawda? [Th: No.] No mam nadzieję, że teraz nie będzie tego. 
Th: No. I właśnie też to jest bardzo dobry przykład dla cudzoziemców poza Europą, że w Polsce mogą yym na przykład te wszystkie studia i te (2) życie jest taniej (3) niż w innych krajach i mogą właśnie zrobić: tutaj skończyć studia i są tak samo zaliczone jak w innych krajach.

(1) Grammatical error-wrong conjugation (masculine instead of nonmasculine gender).

(2) Grammatical error-wrong pronoun inflection.

(3) Grammatical error - use of adverb instead of an adjective.

Th: ...so maybe I would like to finish. I have a similar opinion and I simply think that yyy if someone was doing here, a few years ago finished studies, then maybe they would do something with it in Poland, but in other European countries it was hard for him there. Very well, finished studies in Poland, okay, nothing special. And now, as persons were here speaking already, that yyy...

L: Once you had to recognize those diplomas abroad, you had to pass some additional exams, right? [Th: Yup]. So I hope that now it won't happen.

Th: Yup. And this exactly is a very good example for the foreigners outside Europe, that in Poland they can yym for example all those degrees and this life is more cheaply than in other countries and they can do here: finish the studies here and they are recognized the same as in other countries.

Concluding, it can be said that Thomas fulfilled the role of the co-manager of the discourse very well, contributing a lot to the merits of its content. He also played a big role in giving this dialogue a natural rhythm, presented in frequent utterances, changes of topic and redirecting the conversation to other interlocutors.

\section{Conclusion}

The analysis of two key interlocutors' participation in the conversation: the teacher and Thomas, showed that it is possible to co-manage conversation even when the language competence of the student is insufficient. The teacher, while the student manages the fragments of the discourse, assumes the role of the discourse's architect-she controls the integrity and correctness of utterances, watches over the course of the whole conversation. In short, she ensures that the 'structure' built by their joint effort does not collapse, but instead becomes more beautiful. 'Being at the helm' of the conversation, 'being its architect' does not mean transferring it to the level of didactics, but rather steering it in such a way that the meanings -ideas - are conveyed or negotiated in the best possible way.

In a conversation on a specific topic, the ideology of the discourse is very important-Thomas co-manages this discourse, as he is a skilled ideologist-he can initiate and develop individual threads of the conversation in an interesting way. He is aware of not yet being fit for the role of the discourse's architect-the supermoderator, which is why he has no objection to leaving this to the teacher. 
The conversation develops well because its co-managers, as well as the other participants, do not compete, but cooperate, making it diverse and dynamic. The resulting impression is that, despite the characteristics of classroom discourse, in terms of spontaneity and authenticity, it measures up to the conversations outside the Polish as foreign language class.

The important characteristic of this conversational session is that it took 55 minutes straight only in Polish, with no insertions in any other language. It would not be possible without the emotional commitment of most of the interlocutors into co-managing the dialogue.

\section{References}

Bańko, S. (Ed.) 2000. Inny słownik języka polskiego. Warszawa: Wydawnictwo Naukowe PWN. Bohm, D. 1996. On Dialog, ed. Lee Nichol. London-New York: Routledge.

Byram, M. (Ed.) 2006. Routledge Encyclopedia of Language Teaching and Learning. London and New York: Routledge.

Komorowska, H. 2005. Metodyka nauczania języków obcych. Warszawa: Fraszka Edukacyjna.

Kowalcze, K. 2009. Bilingwizm w sytuacji komunikacyjnej wyrażania emocji. Studium przypadków dwujęzyczności polsko-włoskiej. W: W.T. Miodunka (Ed.) Nowa generacja w glottodydaktyce polonistycznej, 49-83. Kraków: Universitas, Kraków.

Kramsch, C. 1993. Context and Culture in Language Teaching. Oxford: Oxford University Press.

Lewandowska-Tomaszczyk, B. (Ed.) 2005. Podstawy językoznawstwa korpusowego. Łódź: Wydawnictwo UŁ.

Lipińska, E., Seretny, A. 2005. ABC metodyki nauczania języka polskiego jako obcego, Kraków: Universitas

Majer, J. 2003. Interactive Discourse in the foreign Language Classroom. Łódź: Wydawnictwo UŁ.

Niżegorodcew, A. 2009. Foreign language teachers in dialog. W: Kusiak M. (Ed.), Dialog in foreign language education, 11-19. Kraków: Wydawnictwo UJ.

Ostromęcka, B. 1996. Funkcja pytań w procesie glottodydaktycznym, Acta Universitatis Lodziensis. Kształcenie Polonistyczne Cudzoziemców, 7/8, 13-22.

Pawlak, M. 2004. Describing and Researching Interactive process in the Foreign Language Classroom. Konin: Wydawnictwo Państwowej Wyższej Szkoły Zawodowej.

Podsiadły, E., Zarzycka-Suliga G. 1991. Sposoby i środki porozumiewania się cudzoziemców we wstępnym okresie nauczania języka polskiego, Acta Universitatis Lodziensis. Kształcenie Polonistyczne Cudzoziemców, 3, 13-37.

Sacks, H. 1992. Lectures on Conversations. Volumes I \& II, ed. G. Jefferson, introd. E. A. Schegloff. Oxfrod UK-Cambridge USA: Blackwell.

Sinclair, J.H. Mc, Coulthard, M. 1975. Toward an Analysis of Discourse: The English Used by Teachers and Pupils. London: Oxford University Press.

Sokołowska, K. 2011. Rola komentarza lektorskiego jako tekstu podstawowego w nauczaniu obcokrajowców. W: B. Grochala, M. Wojenka (Ed.),Teksty i podteksty w nauczaniu języka polskiego jako obcego - 3, Acta Univesritas Lodziensis.Kształcenie Polonistyczne Cudzoziemców, 18 (w druku).

Tannen, D. 1994. Gender and Discourse. Oxford: Oxford University Press.

Zarzycka, G. 1998. Sposoby negocjowania znaczeń w komunikacji międzykulturowej. W: Socjolingwistyczne i kulturoznawcze elementy w nauczaniu języków obcych w aspekcie 
jednoczącej się Europy, Prace Naukowe Studium Nauki Języków Obcych Politechniki Wrocławskiej, 34/2, 179-197.

Zarzycka, G. 2000a. Dialog międzykulturowy. Teoria oraz opis zachowań społeczno-językowych cudzoziemców przyswajających język polski, Acta Universitatis Lodziensis. Kształcenie Polonistyczne Cudzoziemców nr 11.

Zarzycka, G. 2000b. Socjolingwistyczne uwarunkowania komunikacji międzykulturowej opis badań własnych. W: K. Wojtczuk (Ed.), Socjologiczne aspekty funkcjonowania języka, 123-136, Siedlce: Akademia Podlaska.

Zarzycka, G. 2000c. Uniformizująca funkcja języka propagandowego w kontekście przyswajania języka polskiego jako drugiego. W: K. Michalewski (Ed.) Regulacyjna funkcja tekstów, 407-418, Wydawnictwo Uniwersytetu Łódzkiego, Łódź, 2000.

Zarzycka, G. 2001a. Analiza konwersacji i analiza dyskursu jako metody przydatne w określaniu kompetencji komunikacyjnej.W.R. Cudak, J. Tambor (Eds.), Inne optyki. Nowe programy, nowe metody, nowe technologie w nauczaniu kultury polskiej i języka polskiego jako obcego, 241-255, Katowice: Wydawnictwo Uniwersytetu Śląskiego.

Zarzycka, G. 2001b. Typy zakłóceń w komunikacji międzykulturowej. W: G. Habrajska (Ed.), Język w komunikacji (3), 243-258. Łódź: Wydawnictwo Wyższej Szkoły Humanistyczno-Ekonomicznej.

Zarzycka, G. 2002. O interkulturowej kompetencji komunikacyjnej, Acta Universitatis Lodziensis. Kształcenie polonistyczne cudzoziemców, 12, 11-43.

Zarzycka, G. 2003. 0 walorach badawczych analizy konwersacji (spojrzenie transakcyjne). W: J. Opoka, A. Oskiera (Eds.), Język, literatura, dydaktyka, t. 1, 241-254, Łódź: Wydawnictwo Wyższej Szkoły Humanistyczno-Ekonomicznej.

Zarzycka, G. 2006. Moc dialogu... Przebieg i efekty sesji konwersacyjnych w wielonarodowej grupie studenckiej. W: A. Seretny, E. Lipińska (Ed.), Sprawności przede wszystkim, 129-148, Kraków: Universitas.

Zarzycka, G. 2008. Opis pedagogiki zorientowanej na rozwój kompetencji i wrażliwości kulturowej. W: W. T. Miodunka, A. Seretny, W poszukiwaniu nowych rozwiq̨zań. Dydaktyka języka polskiego jako obcego u progu XXI wieku, 63-77. Kraków: Wydawnictwo Uniwersytetu Jagiellońskiego.

Zarzycka, G. 2010. „Teatr czytelników” jako dialog z tekstem literackim (na przykładzie inscenizacji wiersza Wisławy Szymborskiej „Pogrzeb”. W: G. Zarzycka, G. Rudziński (Eds.), Teksty i podteksty w nauczaniu języka polskiego jako obcego - 2, Kształcenie Polonistyczne Cudzoziemców, 17, 414-424.

Żurek, A. 2008. Grzeczność językowa w polszczyźnie cudzoziemców. Łask: Oficyna Wydawnicza „Leksem”. 